\title{
Chitin Synthase Activity from Neocallimastix frontalis, an Anaerobic Rumen Fungus
}

\author{
By LUCIEN GAY, * MICHEL HÉBRAUD, VINCENT GIRARD AND \\ MICHEL FÈVRE \\ Laboratoire de Différenciation Fongique, CNRS UA 1127, Université Lyon 1, 43 boulevard du \\ 11 novembre 1918, F-69622 Villeurbanne, France
}

(Received 17 June 1988; revised 20 September 1988; accepted 31 October 1988)

Chitin synthase activity was detected in actively growing mycelium of Neocallimastix frontalis after mechanical disruption of the cells. Chitin formation in fungal extracts at $32^{\circ} \mathrm{C}$ was linear with respect to time for at least $60 \mathrm{~min}$, and with respect to protein concentration up to $750 \mu \mathrm{g} \mathrm{ml}^{-1}$. The optimum $\mathrm{pH}$ for enzyme activity was 8.5 using $10 \mathrm{mM}-\mathrm{Tris} / \mathrm{HCl}$ buffer. $\mathrm{Mg}^{2+}$ was necessary for maximum activity and $10 \mathrm{mM}-\mathrm{MgCl}_{2}$ was routinely used during the assays. The apparent $K_{\mathrm{m}}$ for the substrate UDP-GlcNAc was $2 \mathrm{mM}$. Polyoxin D was a competitive inhibitor of chitin synthesis with an apparent $K_{\mathrm{i}}$ of $4 \mu \mathrm{M}$. Following treatment with trypsin $\left(12.5 \mu \mathrm{g} \mathrm{ml}^{-1}\right)$, the chitin synthase activity of the fungal extract increased by six-fold, indicating that most of the chitin synthase activity was zymogenic. The reaction product was insoluble in $1 \mathrm{M}-\mathrm{KOH}$ or $1 \mathrm{M}$-acetic acid, but it was solubilized by heating in $6 \mathrm{M}-\mathrm{HCl}$ at $120^{\circ} \mathrm{C}$ for $2.5 \mathrm{~h}$ and was hydrolysed by chitinase into diacetylchitobiose.

\section{INTRODUCTION}

The membrane-bound enzyme chitin synthase (EC 2.4.1.16) has been isolated from a wide range of fungi (Cabib, 1981), where it plays a major role in cell-wall biosynthesis (Cabib et al., 1979; Gooday \& Trinci, 1980). Studies of chitin synthase in higher fungi or yeasts have contributed to an understanding of the regulation of chitin synthesis, but little information is available about the obligate anaerobic fungus Neocallimastix frontalis, which inhabits the gut of sheep. This chitinous fungus (Orpin, 1977) and related species appear unique in many respects (morphology, life cycle, ability to grow under conditions of low redox potential and in the absence of oxygen). The aim of this study was the characterization of chitin synthase from a laboratory-grown strain of $N$. frontalis.

\section{METHODS}

Preparation of extracts. Neocallimastix frontalis (isolated from sheep rumen) was maintained on the synthetic liquid medium B of Lowe et al. (1985), modified as follows: $\mathrm{Na}_{2} \mathrm{CO}_{3} 8 \mathrm{~g} \mathrm{l}^{-1}$ instead of $80 \mathrm{~g} \mathrm{l}^{-1}$; cellobiose $10 \mathrm{~g}^{-1}$ instead of $3.75 \%$; lysozyme was omitted; the reducing agent solution contained L-cysteine $1 \mathrm{~g} \mathrm{l}^{-1}$ instead of $2.5 \mathrm{~g} \mathrm{l}^{-1}$ and $\mathrm{NaHCO}_{3} 6 \mathrm{~g} \mathrm{l}^{-1}$ instead of $\mathrm{Na}_{2} \mathrm{~S} .9 \mathrm{H}_{2} \mathrm{O} 2.5 \mathrm{~g} \mathrm{l}^{-1}$. Cultures were grown for $72 \mathrm{~h}$ at $39^{\circ} \mathrm{C}$ and harvested by centrifugation ( $8000 \mathrm{~g}$ for $10 \mathrm{~min}$ ). Cells were broken in $10 \mathrm{~mm}$-Tris/ $\mathrm{HCl}$ buffer pH 7.5 plus $2 \mathrm{mM}$ $\mathrm{Na}_{2}$ EDTA, with a Virtis blade homogenizer $\left(20000\right.$ r.p.m. for $3 \times 30$ s) at $4{ }^{\circ} \mathrm{C}$, and the resulting crude homogenate $(\mathrm{CH})$ was centrifuged at $1000 \mathrm{~g}$ for $10 \mathrm{~min}$. The pellet consisted mainly of large cell wall debris (cellwall fraction: $C W F$ ) and was retained. The supernatant fluid was centrifuged at $48000 \mathrm{~g}$ for $30 \mathrm{~min}$; the pellet (mixed-membrane fraction: MMF) and the supernatant fluid (supernatant fraction: SF) were used as sources of enzyme.

\footnotetext{
Abbreviations: $\mathrm{CH}$, crude homogenate; $\mathrm{CWF}$, cell-wall fraction; MMF, mixed-membrane fraction; SF, supernatant fraction; GlcNAc, $N$-acetylglucosamine; UDP-GlcNAc, uridine disphosphate $N$-acetylglucosamine.
} 
Chitin synthase assay. A modification of the method of Raeven (1981) was used. The cell extracts (CWF, MMF) were suspended in $20 \mathrm{mM}$-Tris/ $\mathrm{HCl}$ buffer $\mathrm{pH} 7.5$ containing $10 \mathrm{mM}-\mathrm{MgCl}_{2}$. The standard reaction mixture consisted of $0.5 \mathrm{~mm}-\mathrm{UDP}-\mathrm{GlcNAc}\left[25 \mathrm{nCi}(925 \mathrm{~Bq}) \mathrm{UDP}-\left[\mathrm{U}-{ }^{14} \mathrm{C}\right] \mathrm{GlcNAc}\right.$, sp. act. $302 \mathrm{Ci} \mathrm{mol}^{-1}(11.2 \mathrm{TBq}$ $\mathrm{mmol}^{-1}$ )], $20 \mathrm{~mm}-\mathrm{GlcNAc}, 20 \mathrm{mM}$-Tris/HCl buffer $\mathrm{pH} 8.5,10 \mathrm{mM}-\mathrm{MgCl}_{2}, 12.5 \mu \mathrm{g}$ trypsin $\mathrm{ml}^{-1}$ (bovine pancreas, Boehringer), and $50 \mu \mathrm{l}$ of the enzyme extract, in a final volume of $200 \mu \mathrm{l}$; incubation was for $40 \mathrm{~min}$ at $32^{\circ} \mathrm{C}$. The reaction was stopped with $2 \mathrm{ml} 95 \%(\mathrm{v} / \mathrm{v})$ ethanol and the reaction product was filtered on glass-fibre filters (GF/C, Whatman) and washed successively with $5 \mathrm{ml} 0.5 \mathrm{M}-\mathrm{NaOH}, 2 \times 10 \mathrm{ml} \mathrm{95 \%}$ ethanol/1 M-acetic acid (2:8, $\mathrm{v} / \mathrm{v}$ ), and $2 \times 5 \mathrm{ml} 95 \%$ ethanol.

Specific activity of the enzyme was expressed as nmol GlcNAc incorporated in $1 \mathrm{~min}$ by $1 \mathrm{mg}$ protein (measured by the Lowry method).

Characterization of the reaction product. The reaction mixture was made up to $2 \mathrm{ml}$ and incubated for $2 \cdot 5 \mathrm{~h}$. The reaction was stopped with $6 \mathrm{ml} \mathrm{95 \%}$ ethanol and the material was then centrifuged at $48000 \mathrm{~g}$ for 30 min to yield a radioactive pellet and a clear supernatant. The pellet was suspended in $2 \mathrm{ml}$ distilled water and samples of the suspension were used for the identification of the product, by either enzyme or acid hydrolysis.

For enzyme hydrolysis, $0.8 \mathrm{mg}$ chitinase (Sigma) in $800 \mu 12 \mathrm{~mm}$-sodium phosphate buffer pH 6, containing $80 \mathrm{U}$ penicillin and $24 \mu \mathrm{g}$ streptomycin, was added to $400 \mu \mathrm{l}$ of the radioactive suspension. The mixture was incubated for $20 \mathrm{~h}$ at $30{ }^{\circ} \mathrm{C}$ and the reaction was terminated by the addition of $95 \%$ ethanol. The mixture was either filtered through a glass-fibre filter and its radioactivity measured, or it was subjected to chromatography on cellulose F pre-coated TLC plates (Merck). The chromatograms were developed in $95 \%$ ethanol/1 M-ammonium acetate $(7: 3, v / v)$, butanol/pyridine/water $(6: 4: 3$, by vol.) or ethyl acetate/pyridine/water $(2: 2: 1$, by vol.). The spots were visualized by spraying with silver reagent or ninhydrin (for glucosamine) and were identified by comparing the $R_{F}$ values with those obtained using authentic compounds. The spots were excised and their radioactivity was measured.

For acid hydrolysis, $400 \mu \mathrm{l}$ of the radioactive suspension was hydrolysed with $800 \mu \mathrm{l} 6 \mathrm{M}-\mathrm{HCl}$ at $120^{\circ} \mathrm{C} \mathrm{for} 2 \cdot 5 \mathrm{~h}$ and then chromatographed as described above. Other samples were treated with $1 \mathrm{M}-\mathrm{KOH}$ for $1 \mathrm{~h}$ at $100^{\circ} \mathrm{C}$ or with $1 \mathrm{M}$-acetic acid for $30 \mathrm{~min}$ at $50^{\circ} \mathrm{C}$.

\section{RESULTS}

Distribution of chitin synthase activity. The fractions (CH, CWF, MMF and SF) obtained by differential centrifugation were assayed for their chitin synthase activity (Table 1). Chitin synthase was located mainly in the cell wall fraction $(1000 \mathrm{~g}$ pellet) and the mixed membrane fraction $(48000 \mathrm{~g}$ pellet): the supernatant fraction $(48000 \mathrm{~g}$ supernatant) yielded very little activity. The distribution of the enzyme activity between CWF and MMF varied according to the degree of homogenization: CWF activity was lowered in heavily disrupted extracts ( $3 \times 2$ min homogenization) but MMF activity was not concomitantly increased, showing that the extra membranes released from CWF were disorganized. On average, $60-65 \%$ of the total activity was recovered in CWF, and $30-35 \%$ in MMF. This distribution is consistent with the hypothesis (Vermeulen et al., 1979) that the enzyme is attached to the plasma membrane which can, depending on the homogenization procedure, remain more or less attached to the cell wall. The low specific activity of the crude extract (about half that of CWF or MMF) could be related to inhibitory substances released during homogenization, but it could also be explained by the presence of EDTA in the homogenization buffer, which could interfere with the divalent cations required for the reaction (Orlean, 1987). In control experiments in which MMF was incubated

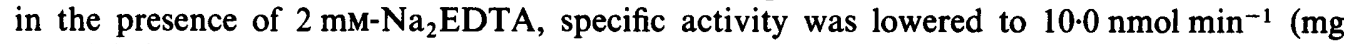
protein $)^{-1}$.

The MMF was used for enzyme characterization due to its greater homogeneity and higher specific activity. Only data from experiments using MMF are presented here, but properties of chitin synthase in CWF resembled those of MMF.

Proteolytic activation of the enzyme. When fungal extracts were pretreated for $30 \mathrm{~min}$ with trypsin (bovine pancreas, Boehringer) $\left(1-50 \mu \mathrm{g} \mathrm{ml}^{-1}\right)$ then with trypsin inhibitor (soybean, Boehringer) (2-200 $\mu \mathrm{g} \mathrm{ml}^{-1}$ ) prior to the chitin synthase assay, enzyme activity was inhibited. Subsequently, trypsin was incorporated in the assay mixture throughout the incubation. The enzyme activity was strongly stimulated (5- to 10-fold) by such protease treatment (Fig. 1), with maximum activity at $12.5 \mu \mathrm{g}$ trypsin $\mathrm{ml}^{-1}$. At higher trypsin concentrations, chitin synthase activity was lower, presumably because of enzyme inactivation. 


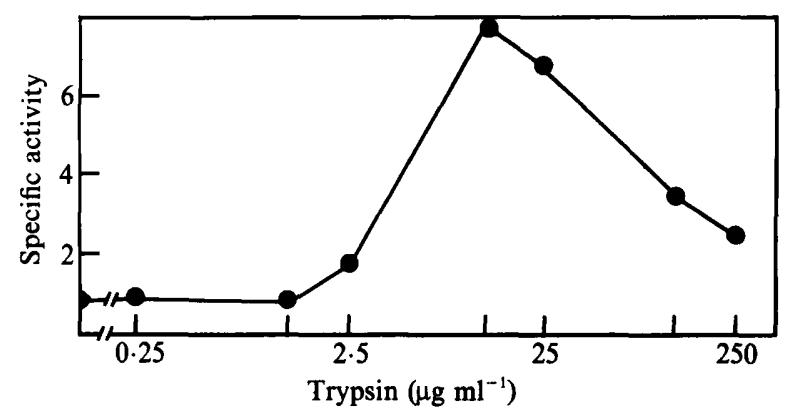

Fig. 1. Effect of trypsin on chitin synthase activity [nmol GlcNAc $\min ^{-1}$ (mg protein) ${ }^{-1}$ ] of MMF $\left(420 \mu \mathrm{g}\right.$ protein $\mathrm{ml}^{-1} ; \mathrm{pH} 7 \cdot 5 ; 24^{\circ} \mathrm{C}$ for $\left.40 \mathrm{~min}\right)$.

\section{Table 1. Distribution of chitin synthase activity in cell-free extracts of $N$. frontalis}

The fractions were prepared and assayed as described in Methods. For each fraction, the results show the specific activity [nmol GlcNAc min $^{-1}$ (mg protein) ${ }^{-1}, \pm$ SD] and the total activity (nmol GlcNAc $\mathrm{min}^{-1}$ ). Activity is also expressed as a percentage of the total activity in all four fractions. All observations were repeated five times.

$\begin{array}{lccccc}\text { Fraction } & \begin{array}{c}\text { Protein } \\ \text { content } \\ \text { (mg) }\end{array} & \begin{array}{c}\text { Percentage } \\ \text { of total } \\ \text { protein }\end{array} & \begin{array}{c}\text { Total } \\ \text { activity }\end{array} & \begin{array}{c}\text { Percentage } \\ \text { of total } \\ \text { activity }\end{array} & \begin{array}{l}\text { Specific } \\ \text { activity }\end{array} \\ \text { CH } & 4.65 & 100 & 30 \cdot 2 & 100 & 6 \cdot 5 \pm 2 \cdot 4 \\ \text { CWF } & 1 \cdot 72 & 37 & 19 \cdot 6 & 60-65 & 11 \cdot 4 \pm 2 \cdot 3 \\ \text { MMF } & 0.60 & 13 & 9.9 & 30-35 & 16.5 \pm 1 \cdot 0 \\ \text { SF } & 2.33 & 50 & 0.7 & 0-5 & 0.3 \pm 0.2\end{array}$

The formation of chitin as a function of time. At a UDP-GlcNAc concentration of $0.5 \mathrm{mM}$, the rate of incorporation of GlcNAc into chitin at $32^{\circ} \mathrm{C}$ was almost linear up to $60 \mathrm{~min}$. The subsequent decline in activity may have been due to the depletion of substrate or to the accumulation of UDP, which may be inhibitory (Raeven, 1981), and perhaps to the destruction of enzyme by trypsin. For further experiments, the reaction was thus always stopped after $40 \mathrm{~min}$ incubation.

Dependence of chitin synthesis on temperature and $\mathrm{pH}$. The optimal temperature for enzyme activity in 40 min assays was about $32^{\circ} \mathrm{C}$, with a sharp decrease in activity at low $\left(14^{\circ} \mathrm{C}\right)$ or high $\left(50^{\circ} \mathrm{C}\right)$ temperatures. This high temperature optimum might relate to the natural environment of the fungus, but this value would also represent a balance between a high initial stimulation of the enzyme and its degradation by trypsin.

The enzyme was assayed at $24^{\circ} \mathrm{C}$ under standard conditions at $\mathrm{pH}$ values ranging from 6 to 9 , using $20 \mathrm{~mm}$-MES or Tris/ $\mathrm{HCl}$ buffers. The synthesis of chitin was very low at $\mathrm{pH} 6$ $\left.[1.6 \mathrm{nmol} \mathrm{min}-1 \text { (mg protein })^{-1}\right]$, and maximal activity was observed at $\mathrm{pH} 8.5\left[9 \mathrm{nmol} \mathrm{min}^{-1}\right.$ (mg protein) $)^{-1}$.

Kinetics and competitive inhibition. Lineweaver-Burk plots of reaction velocity against substrate concentration (0.1-5 mM-UDP-GlcNAc) (Fig. 2a) were linear at high concentration but became sigmoidal at low concentration, as observed by de Rousset-Hall \& Gooday (1975) for chitin synthase from Coprinus cinereus. The apparent $K_{m}$ value for UDP-GlcNAc was about $2 \mathrm{mM}$. With different concentrations of substrate ( 0.5 and $1 \mathrm{mM}-\mathrm{GlcNAc})$, polyoxin $\mathrm{D}$, a specific inhibitor of chitin synthase activity (Endo et al., 1970), acted as a competitive inhibitor; plots of activity vs. inhibitor concentration (ranging from 1 to $100 \mu \mathrm{g} \mathrm{ml}^{-1}$ ) were linear and revealed a $K_{\mathrm{i}}$ of about $4 \mu \mathrm{M}$ (Fig. $2 b$ ). On the other hand, the enzyme activity was stimulated by $20 \mathrm{mM}$ GlcNAc, which acts as an allosteric activator of other chitin synthases (Gooday, 1978). Divalent cations were needed for maximum activity, and $\mathrm{Mg}^{2+}$ was the most efficient of those tested: a 

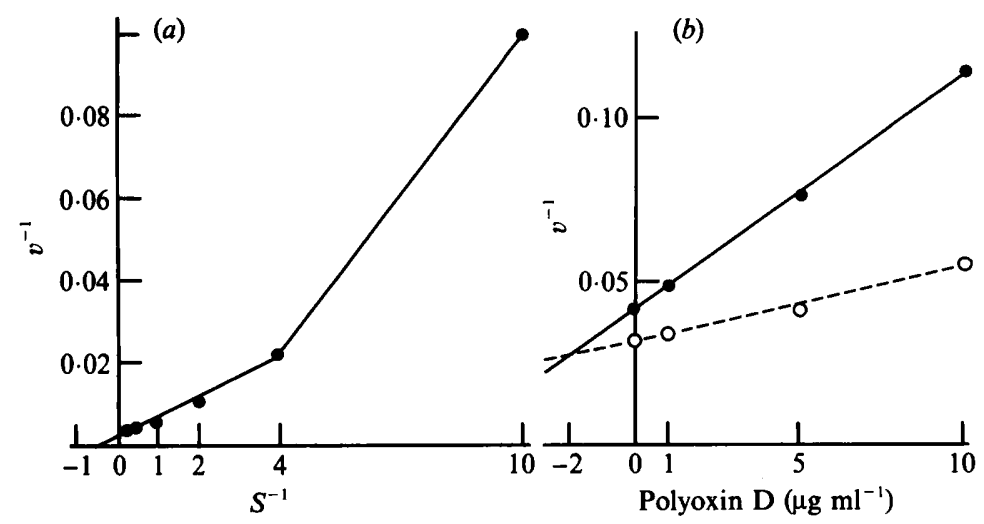

Fig. 2. Effect of substrate concentration and polyoxin D on chitin synthase activity. (a) LineweaverBurk plots of the velocity $\left(v, \mathrm{nmol}\right.$ GlcNAc incorporated $\left.\min ^{-1}\right)$ of chitin synthase activity against substrate concentration ( $S, \mathrm{mM}$ GlcNAc). (b) Effect of polyoxin D concentration on enzyme activity at UDP-GlcNAc concentrations of $1 \mathrm{mM}(\mathrm{O})$ or $0.5 \mathrm{~mm}(\mathbf{O})$.

change of $\mathrm{Mg}^{2+}$ to $\mathrm{Co}^{2+}$ or $\mathrm{Mn}^{2+}$ lowered the specific activity of MMF from 14.6 to 1.7 or $1.2 \mathrm{nmol} \mathrm{m^{-1 }}$ (mg protein) ${ }^{-1}$, respectively.

Identification of the reaction product. Most ( $97 \%$ ) of the radioactivity in the incubated mixture was retained on the glass-fibre filter, indicating that a polymer was produced. Following digestion with chitinase, only $8 \%$ of the radioactivity remained insoluble and the chromatographic analysis of the solubilized fraction $(92 \%$ of the radioactivity) revealed mainly diacetylchitobiose. On strong acid hydrolysis $(6 \mathrm{M}-\mathrm{HCl}), 95 \%$ of the radioactivity was solubilized and chromatograms revealed glucosamine as the only component of the hydrolysed fraction.

The product of the reaction in the incubation mixture was insoluble in $1 \mathrm{M}$-acetic acid or in $1 \mathrm{M}-\mathrm{KOH}$, as respectively $96 \%$ and $93 \%$ of the radioactivity was recovered on glass-fibre filters. Essentially all of the polymer synthesized can thus be accounted for as chitin because the major products obtained from chitinase action or acid hydrolysis were diacetylchitobiose and glucosamine respectively.

\section{DISCUSSION}

This study indicates that most of the properties of chitin synthase extracted from the anaerobic rumen fungus $N$. frontalis are similar to what is known from other fungi (Gooday $\&$ Trinci, 1980). The sugar donor was UDP-GlcNAc with an apparent $K_{\mathrm{m}}$ of $2 \mathrm{~mm}$ but the biphasic nature of the Lineweaver-Burk plots suggests that UDP-GlcNAc is an activator as well as a substrate to the $N$. frontalis chitin synthase and could act as an allosteric effector of the enzyme. The considerable degree of activation of chitin synthase by GlcNAc and $\mathbf{M g}^{2+}$ observed with membrane fractions supports their roles as allosteric activator and cofactor, respectively. The enzyme was largely present in a zymogenic form (presumably the native form: Cabib, 1981) that was activated by limited proteolysis with trypsin $\left(12.5 \mu \mathrm{g} \mathrm{ml}^{-1}\right)$ and UDP-GlcNAc incorporation was competitively inhibited by polyoxin with a $K_{\mathrm{i}}$ of $4 \mu \mathrm{M}$. In contrast to the chitin synthases extracted from aerobic fungi, which are generally active at low temperature $\left(24^{\circ} \mathrm{C}\right)$ and at $\mathrm{pH}$ $<7.5$ [except for Candida albicans (Hardy \& Gooday, 1978) and Coprinus cinereus (Gooday \& de Rousset-Hall, 1975)], $N$. frontalis chitin synthase was more active at $32-39^{\circ} \mathrm{C}$ and its optimum $\mathrm{pH}$ was more alkaline than optima generally reported for this enzyme in other fungi. These properties resemble those of chitin synthase-2 extracted from Saccharomyces cerevisiae (Sburlati $\&$ Cabib, 1986; Orlean, 1987), but the $N$. frontalis enzyme was far more active and was inhibited by $\mathrm{Co}^{2+}$. 
Since chitin is synthesized during the growth cycle of the fungus, chitin synthase activity could be a useful physiological parameter to estimate fungal growth. Further experiments will determine whether chitin synthase activity could be a reliable method to quantify $N$. frontalis biomass.

We wish to thank Dr G. W. Gooday for a critical reading of the manuscript, Dr P. Gouet and G. Fonty (Laboratoire de Microbiologie, INRA, Theix, France) for providing the fungal strain, and C. Bärtschi and Ch. Rascle for technical assistance.

\section{REFERENCES}

CABIB, E. (1981). Chitin: structure, metabolism and regulation of biosynthesis. In Encyclopedia of Plant Physiology New Series, vol. 13B, Plant Carbohydrates II, pp. 395-415. Edited by W. Tanner \& F. A. Loewus. Berlin: Springer Verlag.

Cabib, E., Duran, A. \& Bowers, B. (1979). Localized action of chitin synthase in the initiation of yeast septum formation. In Fungal Walls and Hyphal Growth, pp. 189-201. Edited by J. H. Burnett \& A. P. J. Trinci. Cambridge: Cambridge University Press.

Endo, A., KaKIKI, K. \& Misato, T. (1970). Mechanisms of action of antifungal agent polyoxin $\mathbf{D}$. Journal of Bacteriology 105, 161-164.

GoODAY, G. W. (1978). The enzymology of hyphal growth. In Developmental Mycology, vol. 3, The Filamentous Fungi, pp. 51-77. Edited by J. E. Smith \& D. R. Berry. London: Edward Arnold.

Gooday, G. W. \& DE Rousset-Hall, A. (1975). Properties of chitin synthetase from Coprinus cinereus. Journal of General Microbiology 89, 137-145.

Gooday, G. W. \& TrincI, A. P. J. (1980). Wall structure and biosynthesis in fungi. In The Eucaryotic Microbial Cell, pp. 207-251. Edited by G. W. Gooday, D. Lloyd \& A. P. J. Trinci. Cambridge: Cambridge University Press.

HaRdy, J. C. \& Gooday, G. W. (1978). Chitin biosynthesis by Candida albicans. Proceedings of the Society for General Microbiology 5, 106-107.
Lowe, S. E., Theodorou, M. K., Trinci, A. P. J. \& HeSPELL, R. B. (1985). Growth of anaerobic rumen fungi on defined and semi-defined media lacking rumen fluid. Journal of General Microbiology 131, 2225-2229.

ORLEAN, P. (1987). Two chitin synthases in Saccharomyces cerevisiae. Journal of Biological Chemistry 262, 5732-5739.

ORPIN, C. G. (1977). The occurrence of chitin in the cell walls of rumen organisms Neocallimastix frontalis, Piromonas communis and Sphaeromonas communis. Journal of General Microbiology 99, 215-218.

RAEVEN, M. B. J. M. (1981). Biosynthesis of chitin in fungi. PhD thesis, University of Groningen, The Netherlands.

DE Rousset-Hall, A. \& Gooday, G. W. (1975). A kinetic study of a solubilized chitin synthetase preparation from Coprinus cinereus. Journal of General Microbiology 89, 146-159.

Sburlati, A. \& CABIB, E. (1986). Chitin synthetase 2, a presumptive participant in septum formation in Saccharomyces cerevisiae. Journal of Biological Chemistry 261, 15147-15152.

Vermeulen, C. A., RaeVen, M. B. J. M. \& Wessels, J. G. H. (1979). Localization of chitin synthase activity in subcellular fractions of Schizophyllum commune protoplasts. Journal of General Microbiology 114, 8797. 